\title{
Small Islands Landscape Use Mapping and Its Patches Spatial Structure Analysis at Parang Islands, Karimunjawa National Park, Indonesia
}

\author{
Muhammad Helmi ${ }^{1,2 *}$, Nurfatin Adibah ${ }^{3}$, Rikha Widiaratih ${ }^{1}$, Hariyadi ${ }^{1}$, and Ibnu Pratikto ${ }^{4}$ \\ ${ }^{1}$ Oceanography Department, Faculty of Fisheries and Marine Science, Universitas Diponegoro, J1. Prof. \\ Sudharto, SH., Tembalang, Semarang, Central Java (50275) Indonesia \\ ${ }^{2}$ Center for Coastal Disaster Mitigation and Rehabilitation Study (CoREM), Universitas Diponegoro, Indonesia \\ ${ }^{3}$ Universiti Malaysia Terengganu, 21300, Kuala Terengganu, Terengganu, Malaysia \\ ${ }^{4}$ Marine Science Department, Faculty of Fisheries and Marine Science, Universitas Diponegoro \\ E-mail: *muhammadhelmi69@gmail.com
}

\begin{abstract}
The results of small islands landscape ecology analyses within remote sensing science are not widely discovered on the inferential capabilities of such research. This issue presents a series of papers on the use of landscape ecology techniques to explore the landscape use and its patches spatial structure patterns. The aim of this research are to map the landscape use patches based on GeoeEye-1 high resolution satellite image and to assess its patches spatial structure. This prototype research was conducted at Parang Islands, Karimunjawa National Park that was inhabitant and used for complex anthropogenic activities long time before the national park status establish. Significant accuracy for landscape use map has done using overall accuracy, producer and user accuracy, and Kappa index methods. The analyses focus on the variation and composition of landscape use and the value of its patch spatial structure to dealing with national park policy and management.
\end{abstract}

Keywords: GIS, Karimunjawa, landscape, remote sensing, spatial structure

\section{INTRODUCTION}

Parang Islands is part of Karimunjawa Islands National Park that consists of Parang and Kumbang Island (Prasetya, et. al., 2017, and Helmi et al., 2018b). Both islands are located on one coverage of coral reef seascape and become one of the famous ecotourism in Indonesia. It has become one of the priority areas of marine tourism in Indonesia, which supports educational activities, research, aquaculture, and recreation (Prasetya, et. al., 2017). This national park is a marine protected area that makes efforts to conserve and protect the natural ecosystem in the form of coral reef, sea grass, mangrove, beach forest, and low land tropical forest. The abundant biodiversity and natural resources, beautiful coastal scenery and beautiful shallow waters are a great natural asset in this national park (Helmi et al., 2018b). The richness of natural resources is the main consideration and underpinning these small islands is the choice to live and settle its inhabitants (Li, et.al 2004, and Kupfer, 2012).

The residents have lived in this area long before the status of this national park was established (Helmi et al., 2018a). Population growth in this region is relatively high (Helmi et al., 2018a) with resource utilization activities in complex landscapes. The utilization of landscape causes a dynamic change of the types, shapes, and patterns of the distribution of landscapes in the region (Kupfer, 2012). Patches of the coastal forest become bush due to timber extraction, agricultural land and settlements, and open land. The degradation of mangrove forests will have an impact on the high sedimentation in these waters.

Anthropogenic activities can disrupt the structural integrity of landscapes use and change the shape of environmental factors that can affect the disruption and migration of organisms across the landscape (Cardille, et. al., 2005, Kupfer, 2011, and Hidayati, et. al., 2018). The natural ecosystem damage has occurred in the region, such as damage to coral reef, sea grass beds, mangroves, beach forests, and lowland tropical forests (Prasetya, et. al., 2017, Suripin, et. al, 2017, Helmi et.al, 2018a and Helmi et.al., 2018a). The landscape is composed of mosaic patches and each of these patches has certain unique patterns (Langford, et. al., 2006). Landscape ecology is an approach that states landscape patterns that strongly influence ecological processes (Hergis, et.al., 1999 and Kupfer, 2011). Landscape ecologists have used a variety of terms to refer to the basic elements of a landscape, including ecotope, 
biotope, landscape component, landscape element, landscape unit, landscape cell, geotope, facies, habitat, and site (Hergis, et.al., 1999 and Kupfer, 2011). A disruption in landscape patterns can interfere with its functional integrity, interfering with the critical ecological processes for population persistence, and the maintenance of biodiversity and ecosystem health (Jacob, 1960 and Kupfer, 2011).

The purpose of this research is 1) to map the landscape use patches based on GeoeEye-1 highresolution satellite image, and 2) to assess the patch's spatial structure of landscape use at the study area. This method was applied in Parang Islets, Karimunjawa Marine National Park, Central Java. Parang Islets consists of Parang and Kumbang Island which are united by mangrove ecosystems. These populated islands are the western part of Karimunjawa Marine National Park. The anthropogenic activities in those few places were very complex and have impacted the mangrove ecosystem and coral reef ecosystem damage, such as fishing, ecotourism, harbor, and sea lanes, aquaculture, services, etc (Helmi, et al. 2018a and Helmi et al., 2018b). In this conservation area, there is a common utilization zone and a preservation zone.

In some locations found eroded sandy beaches and coral damage due to waves that need to be handled immediately. Scientific data and publications of land use conditions on these islands are rarely found. Parang Islets can be an ideal site as a study area, prototypes for the implementation of this landscape structure method. Mapping the landscape use patch needs to be done to be a baseline of landscape structure characteristics. Early mapping is a complement to the archipelago land resource inventory for future monitoring.

\section{METHODOLOGY}

\subsection{Study area}

Research area was located at the Parang Islands that consist of Parang and Kumbang Islands. Both islets are located in the western part of Karimunjawa National Park, Jepara Regency, Central Java, Indonesia as shows in Figure 1.

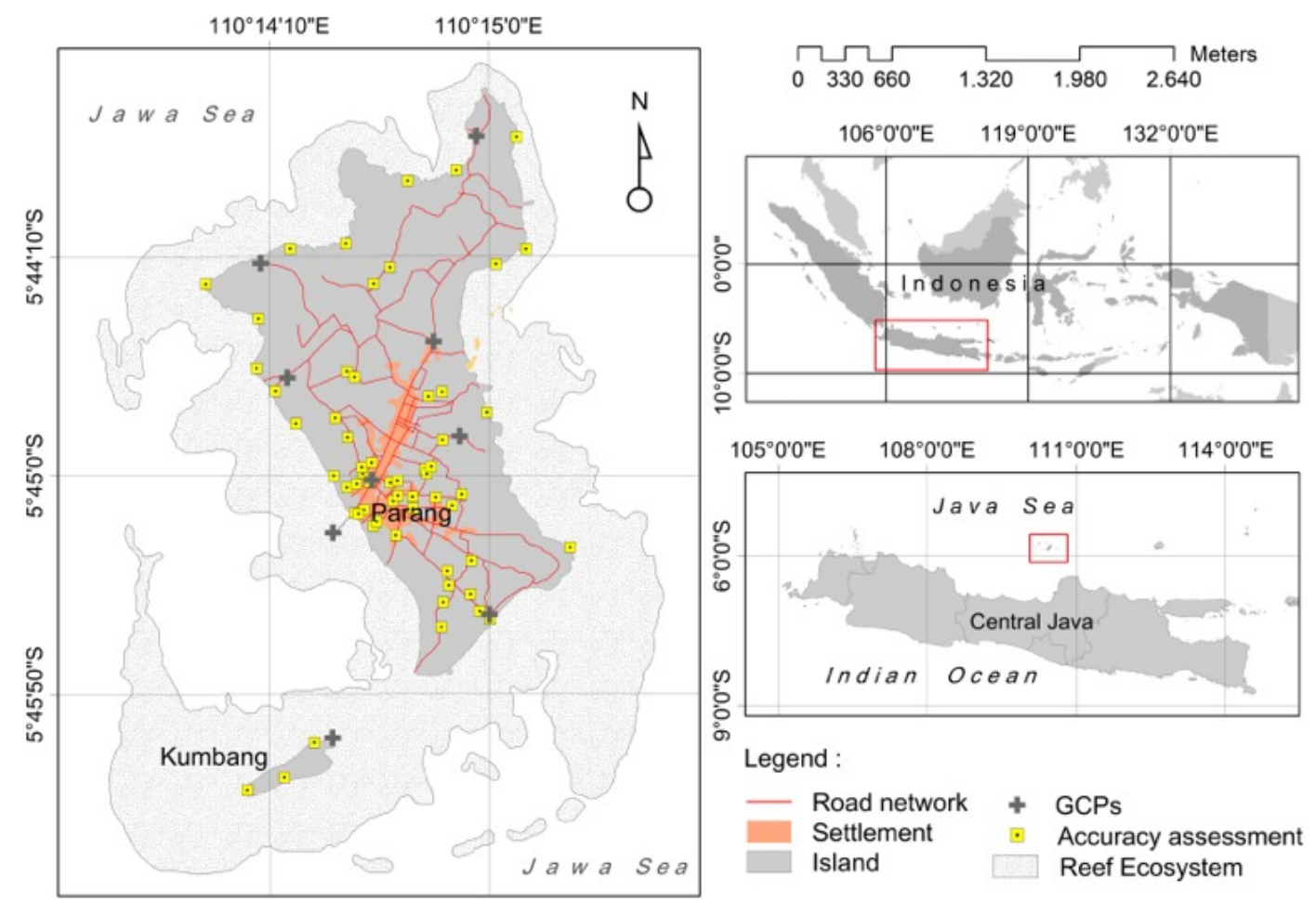

Figure 1. The research area 


\subsection{Satellite Image Processing}

\section{a. GeoEye-1 Satellite Image}

This research using GeoEye-1 satellite image that record on July $16^{\text {th }}, 2011$. The GeoEye-1 satellite data is under the courtesy of GeoEye Inc. USA. It was used has 4 multispectral bands, spatial resolution $1.84 \times 1.84 \mathrm{~m}^{2}, 11$ bits, 4500 columns and 6394 rows of pixels on the Geotiff format. The pre-processing on this satellite image conduct radiometric and geometric correction.

b. Radiometric Correction

Radiometric correction is need to reduce atmospheric scattering, absorption and to minimize the light attenuation interference by the atmospheric constituents (Lillesand, and Kiefer, 2008, Danoedoro, 2012, and Kabiri, et. al., 2013). It correction was done using DOS (Dark Object Subtraction) method to remove the additive haze component or path radian on each single band on the image (Wicaksono, and Hafiz, 2013).

c. Geometric Correction

Geometric correction conduct using ortho-rectification method based using GeoEye-1 sensor model named RPC (Rational Polynomial Coefficient). Two other data has been used to conduct this process, such as $10 \times 10 \mathrm{~m}^{2}$ spatial resolution of DEM (Digital Elevation Model), and eight GCPs (Ground Control Points). The DEM data was developed from the gridding process of both spot height and contour line of topographic map (Hartoko, et. al. 2016, and Satriadi, et. al. 2018), scale 1:25000 that published on 2012 (map source: Indonesia Geospatial Information Agency). The geometry reference was developed on datum WGS84, and projection UTM (Universal Transverse Mercator) South-49. The GCPs was perform in the field using GPS Map76 as show in Figure 1. The location of the GCPs has been determined based on the GeoEye-1 satellite image. Eight points of GCPs were chosen that could be identified in the image and in the field, easily accessible to the location, and the location was spread evenly on the island.

d. Patches Type Mapping

Parang Islands is perform by natural and human patches mosaic. The patches was mapped using GeoEye-1 image and field observation. Each patches was mapped base on it visual characteristic on the computer screen of GeoEye-1 image display (Setyawidati, et. al., 2017). To have a good image display on this research using true color composite image combination, linier starching and image enhancement. Nine interpretation keys i.e. tone, color, shape, pattern, structure, texture, site, and its association was used to identify the boundary of each patch types on the image. The patches was delineated and mapped using on-screen digitizing method and provide it patch name on the GIS database. On this process order several object have also mapped such as coastline, coral reef ecosystem, settlement and road network.

\subsection{Field Survey}

Field surveys were conducted to determine the type of patches that were not recognized in satellite image images, and to do patches type data collection to test the accuracy of patch map. The type of patch identification for the accuracy test is carried out in 60 locations as in Figure 1.

\subsection{Acurracy Asessment}

The map of patches type in this study are tested for accuracy to determine the suitability between the maps with what is in the field. The method of accuracy test used is as follows.

\section{a. Overall Accuracy}

According to Sutanto (2013), accuracy for all categories obtained by summing correctly interpreted pixels (along the diagonal of the Configuration Matrix) divided by the total number of interpreted pixels. The accuracy of all classes (categories) in percent (\%) can be calculated by summing correctly interpreted pixels (on diagonal) divided by the total number of pixels tested. According to Sutanto (2013) the correctness accuracy is equal to or greater than $80 \%$.

b. Accuracy of each class (category); 
Insurance of each class (category), consisting of user accuracy and producer accuracy. User accuracy, i.e. the correct number of pixels in a class (category) divided by the total pixels tested by line (omission error). Producer accuracy, the correct number of pixels in a class (category) divided by total pixels tested by column (commission error).

\section{c. Kappa Index}

The Kappa Index to determine the resulting test score does not occur by chance. This Kappa Index is one of the multivariate discrete techniques to assess accuracy using the Chart statistical analysis (Sutanto, 2013) like the algorithm below.

$$
K=\frac{N \sum_{i=1}^{r} x_{i j}-N \sum_{i=1}^{r}\left(x_{i+\cdot} \cdot x_{+i}\right)}{N^{2}-\sum_{i=1}^{r}\left(x_{i+} \cdot x_{+i}\right)}
$$

$K$ equation represents that $\mathrm{r}$ : number of rows in the confusion matrix, $x_{i j}$ : number of observations on the first line and on the main diagonal, $x_{i+}$ : number of observations on the first line, $x_{+i}$ : number of observations in the first row, and $N$ : total number of observations (pixels) of the matrix.

\subsection{Patches Spatial-Structure Analysis}

The spatial structure studied was patches type using the approach developed by McGarigal et. al. (2002) consist of patches characteristic and diversity index. Patches characteristic including class area, number of patch, patch density, largest patch index, and shape index. Diversity index including total area of landscape, patch richness, shannon's diversity index, simpson's diversity index, shannon's evenness index, and simpson's evenness index. Patches characteristic and diversity index quantify based on patches spatial structure using Fragstats software. Fragstats was developed to compute a wide variety of patches in the landscape metrics for categorial map patterns that has successfully applied for landscape ecology. Main contain of the landscape ecological theory is that the spatial pattern of organisms, populations, and ecosystems across a landscape reflects the influence of underlying gradients and processes but responds to shape ecological processes such as dispersal, competition, disturbance, and fluxes of energy and matter across space (McGarigal et. al., 2002, and (Kupfer, 2011). Correlation analysis involving landscape metrics is produced by the difficulty of replicating large-scale experiments and the complicated responses of metrics to changes in scale and spatial pattern (Kupfer, 2011). Relationships between some metrics and ecological patterns or processes can be founded by interactions with other relation of the landscape (McGarigal et. al., 2002). Landscape metrics are quantitative indices that describe compositional and spatial aspects of landscapes based on data from maps, remotely sensed images and GIS coverage ( $\mathrm{Li}$ and, $\mathrm{Wu}, 2004)$.

While landscape metrics have been developed to describe aspects of patch edge, shape, diversity and evenness, contagion and interspersion, and contrast (Shao and, Wu, 2008). While 'Fragstats style' metrics continue to be widely used, they have well-documented limitations that have led some to question whether many can be related to real-world ecological processes in a predictable manner. Metric values are sensitive to data resolution, study area extent, and thematic resolution of the input data (McGarigal et. al., 2002), and even what are regarded as acceptably low misclassification rates in the source data can be magnified into substantial errors in metric values (McGarigal et. al., 2002). The equation of each spatial structure of patches on this study are show on Table 1.

Table 1. Landscape Characteristic and Diversity Metric Index (McGarigal et. al., 2002).

\begin{tabular}{|c|c|l|}
\hline Index & Equation & \multicolumn{1}{c|}{ Description } \\
\hline Total Area & $T A=A\left(\frac{1}{10.000}\right)$ & $\begin{array}{l}\mathrm{A}=\text { total landscape area }(\mathrm{m} 2) . \\
\text { Units: Hectares } \\
\text { Total area (TA) often does not have a great deal of interpretive }\end{array}$ \\
\hline
\end{tabular}




\begin{tabular}{|c|c|c|}
\hline & & $\begin{array}{l}\text { value about evaluating landscape pattern, but it is used in the } \\
\text { computations for many of the class and landscape metrics. }\end{array}$ \\
\hline Class Area & $C A=\sum_{j=1}^{n} a_{i j}\left(\frac{1}{10.000}\right)$ & $\begin{array}{l}\text { aij = area }(\mathrm{m} 2) \text { of patch } \mathrm{ij} . \\
\text { Units: Hectares } \\
\text { Class Area is a measure of landscape composition; specifically, } \\
\text { how much of the landscape is comprised of a particular patch } \\
\text { type. Class Area is used in the computations for many of the } \\
\text { class and landscape metrics. }\end{array}$ \\
\hline $\begin{array}{l}\text { Number of } \\
\text { Patches }\end{array}$ & $\mathrm{NP}=n_{i}$ & $\begin{array}{l}\mathrm{ni}=\text { number of patches in the landscape of patch type (class) } \mathrm{i} . \\
\mathrm{NP} \text { equals the number of patches of the corresponding patch } \\
\text { type (class). } \\
\text { Number of patches of a particular patch type is a simple measure } \\
\text { of the extent of subdivision or fragmentation of the patch type. }\end{array}$ \\
\hline $\begin{array}{c}\text { Patch } \\
\text { Density }\end{array}$ & $P D=\frac{n_{i}}{A}(10,000)(100)$ & $\begin{array}{l}\text { ni = number of patches in the landscape of patch type (class) i. } \\
\mathrm{A}=\text { total landscape area }(\mathrm{m} 2) \text {. } \\
\text { Patch density is a limited, but fundamental, aspect of landscape } \\
\text { pattern. Patch density has the same basic utility as number of } \\
\text { patches as an index, except that it expresses number of patches } \\
\text { on a per unit area basis that facilitates comparisons among } \\
\text { landscapes of varying size. }\end{array}$ \\
\hline Shape Index & Shape $=\frac{.25 P_{i j}}{\sqrt{a_{i j}}}$ & $\begin{array}{l}\text { pij }=\text { perimeter }(\mathrm{m}) \text { of patch } \mathrm{ij} . \\
\text { aij }=\text { area }(\mathrm{m} 2) \text { of patch } \mathrm{ij} . \\
\text { Shape index corrects for the size problem of the perimeter-area } \\
\text { ratio index (see previous description) by adjusting for a square } \\
\text { standard and, as a result, is the simplest and perhaps most } \\
\text { straightforward measure of shape complexity. }\end{array}$ \\
\hline $\begin{array}{l}\text { Patch } \\
\text { Richness } \\
(\mathrm{PR})\end{array}$ & $P R=m$ & $\begin{array}{l}\mathrm{m}=\text { number of patch types (classes) present in the landscape, } \\
\text { excluding the landscape border if present. } \\
\text { PR equals the number of different patch types present within the } \\
\text { landscape boundary. } \\
\text { Patch richness is perhaps the simplest measure of landscape } \\
\text { composition, but note that it does not reflect the relative } \\
\text { abundances of patch types. }\end{array}$ \\
\hline $\begin{array}{l}\text { Shannon's } \\
\text { Diversity } \\
\text { Index } \\
\text { (SHDI) }\end{array}$ & $S H D I=-\sum_{i=1}(P$ & $\begin{array}{l}\mathrm{Pi} \text { =proportion of the landscape occupied by patch type (class) } \\
\mathrm{i} \text {. } \\
\text { Shannon's diversity index is a popular measure of diversity in } \\
\text { community ecology, applied here to landscapes. Shannon's } \\
\text { index is somewhat more sensitive to rare patch types than } \\
\text { Simpson's diversity index. }\end{array}$ \\
\hline $\begin{array}{l}\text { Simpson's } \\
\text { Diversity } \\
\text { Index (SIDI) }\end{array}$ & $S I D I=1-\sum_{i=1} P_{i}^{2}$ & $\begin{array}{l}\mathrm{Pi}=\text { proportion of the landscape occupied by patch type (class) } \\
\text { i. } \\
\text { Simpson's diversity index is another popular diversity measure } \\
\text { borrowed from community ecology. Simpson's index is less } \\
\text { sensitive to the presence of rare types and has an interpretation } \\
\text { that is much more intuitive than Shannon's index. Specifically, } \\
\text { the value of Simpson's index represents the probability that any } \\
\text { two pixels selected at random would be different patch types. }\end{array}$ \\
\hline
\end{tabular}




\begin{tabular}{|l|l|l|}
\hline $\begin{array}{l}\text { Shannon's } \begin{array}{l}\text { Evenness } \\
\text { Index (SHEI) }\end{array} \\
\text { SHEI }=-\frac{\sum_{i=1}^{m}\left(P_{i x} \ln P_{i}\right)}{\ln m}\end{array}$ & $\begin{array}{l}\mathrm{Pi}=\text { proportion of the landscape occupied by patch type (class) } \\
\mathrm{i} . \\
\mathrm{m}=\text { number of patch types (classes) present in the landscape, } \\
\text { excluding the landscape border if present. } \\
\text { Shannon's evenness index is expressed such that an even } \\
\text { distribution of area among patch types results in maximum } \\
\text { evenness. As such, evenness is the complement of dominance. }\end{array}$ \\
$\begin{array}{l}\text { Simpson's } \\
\text { Index (SIEI) }\end{array}$ & $S I E I=\frac{1-\sum_{i=1}^{m} P_{i}^{2}}{1-\left(\frac{1}{m}\right)}$ & $\begin{array}{l}\mathrm{Pi}=\text { proportion of the landscape occupied by patch type (class) } \\
\mathrm{i} . \\
\mathrm{m}=\text { number of patch types (classes) present in the landscape, } \\
\text { excluding the landscape border if present. } \\
\text { Simpson's evenness index is expressed such that an even } \\
\text { distribution of area among patch types results in maximum } \\
\text { evenness. As such, evenness is the complement of dominance. }\end{array}$ \\
\hline
\end{tabular}

Each patch is quantified using above algorithm and shows on the two differences table and analysis its patches characteristic and diversity index.

\section{RESULT AND DISCUSSION}

The results of the ortho-rectification process of GeoEye-1 images are shown in Figure 1 with $\mathrm{RMSE}=0.87$. For the satellite images with spatial resolution $=1.84 \mathrm{~m}$ (GeoEye- 1$)$, its RMSE indicates that the field geometry error of the image is $1.6 \mathrm{~m}$ (lower than image spatial resolution). RMSE shows this study produce a good geometry, and can be used to the various mapping purposes.

The quality of the patches map can be seen from the pattern, and the detail delineation of the types of patches performed. The delineation and mapping of patch types in this study perform on 1:5000 scale of map display to have a detail and accurate delineation of each patch on the image. The details of delineation and mapping of patches are shown in Figure 2.

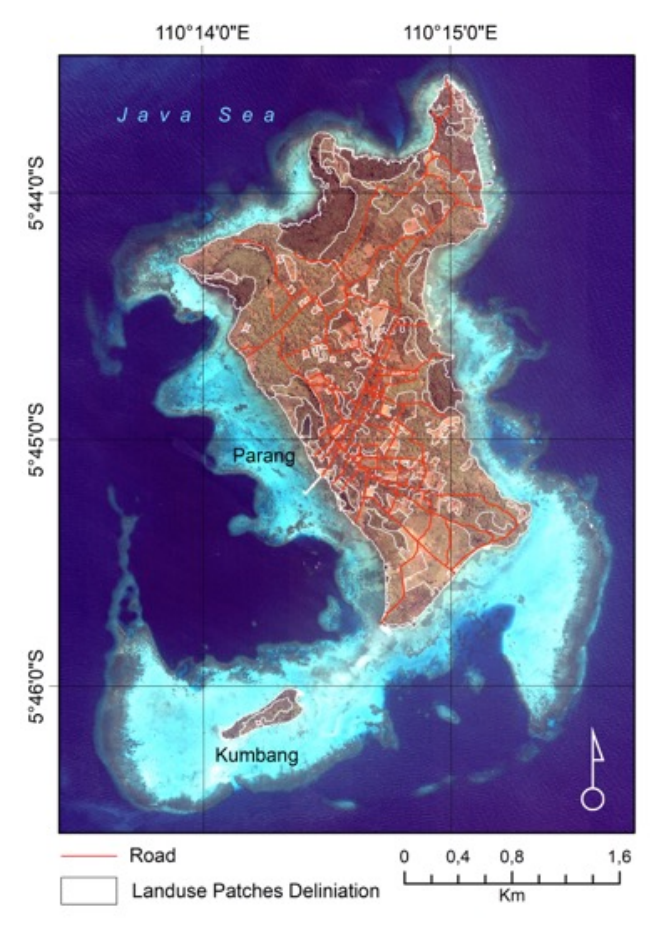

Figure 2. Patch delineation and mapping on the GeoEye-1 image. 
This study shows that landscape patches types in Parang Islands based on GeoEye-1 image consist of six patches, i.e. beach forest, shrubs, mixed garden, barren land mangrove, and settlement. The spatial pattern and distribution of each type of patches is shown in the Figure 3.

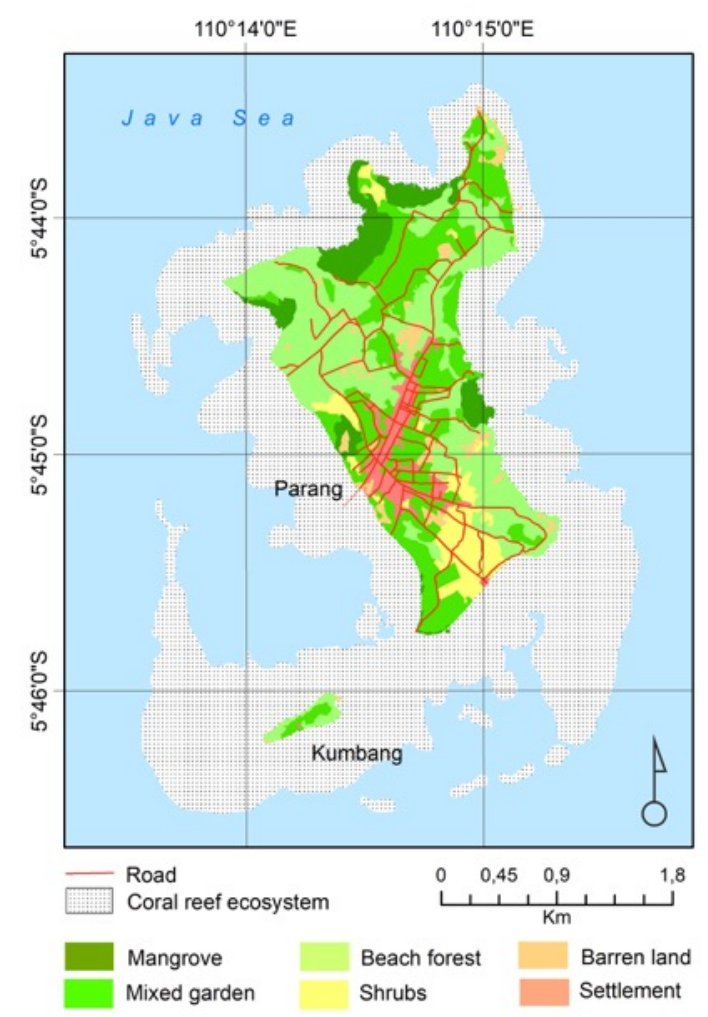

Figure 3. Patch types of small island map at Parang Islands landscape.

The following describes the analysis of the patches of landscape use accuracy in the study area. This accuracy is calculated according to the number of survey locations planned to determine the level of accuracy between patches on the map and existing conditions in the field. Table 2 shows the number of true and false patches on the map based on the survey results in the form of a confusion matrix.

Table 2. Comparison between the use of landscape patches from satellite mapping results in the field in the form of Confusion Matrix

\begin{tabular}{|c|c|c|c|c|c|c|c|c|c|c|c|c|}
\hline \multirow{2}{*}{\multicolumn{2}{|c|}{ Object }} & \multicolumn{7}{|c|}{ Patch map } & \multicolumn{4}{|c|}{ Patch Map Accuracy } \\
\hline & & $B f_{i}$ & $\mathrm{~S}_{\mathrm{i}}$ & $\mathrm{Mg}_{\mathrm{i}}$ & $\mathrm{Bl}_{\mathrm{i}}$ & $\mathrm{M}_{\mathrm{i}}$ & $\mathrm{St}_{\mathrm{i}}$ & Total & $\mathrm{P}_{\mathrm{a}}(\%)$ & $\mathrm{U}_{\mathrm{a}}(\%)$ & $\mathrm{O}_{\mathrm{a}}(\%)$ & $\mathrm{Ki}$ \\
\hline \multirow{6}{*}{ 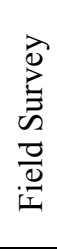 } & $\mathrm{Bf}$ & 9 & 1 & 1 & & & & 11 & 90.0 & 81,8 & \multirow{6}{*}{86.7} & \multirow{6}{*}{0.83} \\
\hline & $\mathrm{S}$ & 1 & 12 & 1 & & & & 14 & 80.0 & 85,7 & & \\
\hline & $\mathrm{Mg}$ & & 1 & 13 & 1 & & & 15 & 81,3 & 86,7 & & \\
\hline & $\mathrm{Bl}$ & & & 1 & 8 & & & 9 & 88,9 & 88,9 & & \\
\hline & $\mathrm{M}$ & & 1 & & & 5 & & 6 & 100,0 & 83,3 & & \\
\hline & $\mathrm{St}$ & & & & & & 5 & 5 & 100,0 & 100,0 & & \\
\hline & Total & 10 & 15 & 16 & 9 & 5 & 5 & 60 & & & & \\
\hline
\end{tabular}

Note on field survey $B f=$ beach forest, $S=$ shrubs, $M g$ = mixed garden, $B l=$ barren land, $M=$ mangrove, and $S t=$ settlement. Note on patch map $B f_{i}=$ beach forest, $S_{i}=$ shrubs, $M g_{i}=$ mixed garden, $B l_{i}=$ barren land, $M_{i}=$ mangrove, and $S t_{i}=$ settlement. Note on patch map accuracy $P_{a}=$ producer accuracy, $U_{a}=$ user accuracy, $O_{a}=$ Overall accuracy, and $K i=$ kappa index. 
This study uses 60 sites survey at Parang and Kumbang Island. The number on the diagonal indicates the number of stations that are correct or appropriate between the mapping results and the existing conditions in the field at the time of survey. The number outside the diagonal shows the number of patches that do not match between what is on the map and what is found in the field. The matrix confusion table is the basis for calculating the accuracy shown in Table 2. Table 2 shows the overall accuracy of patch maps in the study area is $86.7 \%$.

This accuracy indicates that the map is accurate and acceptable for various landscape assessments (tolerable accuracy $\geq 80 \%$ ). This study not only assesses overall patches accuracy, but also user accuracy and producer accuracy that represent accuracy of each patch category on the landscape area. Producer Accuracy in each patch category mapped also has a high accuracy (above tolerable accuracy value $=$ $88.9 \%$ ). The results of this statistical analysis show that the patch map produced in the Parang Islands area is accurate and can be used for various studies that require high accuracy of mapping results. A deeper analysis of the matrix of contents (confusion matrix) produce a kappa index value of 0.83 . This value indicates a positive value as an indicator that the mapping results are good and acceptable with values close to 1.0 (very accurate).

Table 3. Patches Characteristic of Parang Islands Landscape

\begin{tabular}{clrrrrrr}
\hline No. & Patches & CA (ha) & CA (\%) & NP & PD & LPI (ha) & \multicolumn{1}{c}{ SI } \\
\hline 1 & Mangrove & 46.75 & 10.11 & 11 & 2.38 & 4.61 & 5.45 \\
2 & Beach forest & 186.11 & 40.23 & 4 & 0.86 & 37.65 & 8.21 \\
3 & Shrubs & 39.11 & 8.45 & 11 & 2.38 & 6.27 & 4.90 \\
4 & Mixed garden & 141.89 & 30.67 & 24 & 5.19 & 8.11 & 9.49 \\
5 & Barren land & 21.34 & 4.61 & 61 & 13.19 & 0.69 & 12.07 \\
6 & Settlement & 27.37 & 5.92 & 9 & 1.95 & 5.34 & 6.01 \\
\hline
\end{tabular}

Note: $\mathrm{CA}=$ Class Area, $\mathrm{NP}=$ Numb. of Patch, $\mathrm{PD}=$ Patch Density, LPI $=$ Largest Patch Index, and SI $=$ Shape Index.

Table 3 shows patches that dominate in the study area are beach forest $(40.2 \%)$, mixed garden (30.7\%), mangrove (10.1\%) and shrubs (8.5\%). There are no anthropogenic disturbances in the natural patches of mangroves and beach forests, seen from the small number of patches (mangrove NP $=11$ and beach forest $=4)$, and very small patch density ( $\mathrm{PD}$ mangrove $=2.38$ and beach forest $=0.87)$. The widest area of mangrove patch (LPI) is 4.61 ha and beach forest 37.64 ha. Based on the spatial structure possessed, the beach forest patch $(\mathrm{SI}=8.21)$ has a high level of resistance as seen from its value which is close to 1.0 , while mangrove resistance $(\mathrm{SI}=5.45)$ is in the medium category.

Table 4. Diversity Index of Parang Islands Landscape

\begin{tabular}{cccccc}
\hline TA (ha) & PR & SHDI & SIDI & SHEI & SIEI \\
\hline 462.56 & 6 & 1.52 & 0.73 & 0.85 & 0.88 \\
\hline
\end{tabular}

Note: $\mathrm{TA}=$ Total Area, $\mathrm{PR}=$ Patch Richness, SHDI $=$ Shannon's Diversity Index, SIDI $=$ Simpson's Diversity Index, SHEI = Shannon's Evenness Index, and SIEI = Simpson's Evenness Index.

Table 4 shows that the Total Area of the patches in the landscape use reaches 462.56 ha. Parang Island is known to have an area of 453.3 ha and Kumbang 9.4 ha. Parang Islands have diversity index consisting of Patch Richness $=6$, Shannon's Diversity Index $=1.52$, Simpson's Diversity Index $=0.73$, Shannon's Evenness Index $=0.85$, and Simpson's Evenness Index $=0.88$. This condition can be categorized as being in good condition. The characteristics of this landscape are dynamic according to anthropogenic interventions in this region. The characteristics of patches and diversity index of landscapes are baselines to assess the level of conservation or the extent of damage in the future. 


\section{CONCLUSION}

Patches Mapping on the Parang islands landscape can be done using GeoEye-1 satellite imagery with high accuracy (overall accuracy $=86.7 \%$, producer and user accuracy $>81 \%$, and kappa index: $0.83)$. Parang islands landscape is dominated by the area of beach forest patch $(40.2 \%)$, mixed garden (30.7\%), mangrove (10.1\%) and Shrubs (8.5\%). Natural patches of mangroves and beach forests have not been affected by anthropogenic disturbances, as seen from the relatively small number of patches (mangrove $\mathrm{NP}=11$ and beach forest $=4$ ) and very small patch density ( $\mathrm{PD}$ mangrove $=2.38$, and beach forest $=0.87$ ). The largest patch (LPI) of mangroves in the study area is $4.61 \mathrm{ha}$, and beach forest is 37.64 ha. Based on the spatial structure, the beach forest patch type $(\mathrm{SI}=8.21)$ has a higher resistance level than the mangrove $(\mathrm{SI}=5.45)$. Parang Islands have diversity index i.e. Patch Richness $=6$, Shannon's Diversity Index $=1.52$, Simpson's Diversity Index $=0.73$, Shannon's Evenness Index $=0.85$, and Simpson's Evenness Index $=0.88$. Patches characteristic and diversity index landscape produced from this study is a baseline or basis for assessing the success level of conservation or the level of damage in the future.

\section{ACKNOWLEDGMENT}

Appreciation to CoREM (Center for Coastal Disaster Mitigation and Rehabilitation Study), Universitas Diponegoro for the Remote Sensing Laboratory Facilities. We were also grateful to PT. Waindo SpecTerra for the support of the using ArcGIS software ver. 10.4, and ER Mapper software ver. 7.1.

\section{REFFERENCES}

Cardille, J., M. Turner, and M. Clayton. 2005. Metaland: Characterizing Spatial Patterns and Statistical Context of Landscape Metrics. Bioscience 55: 983-988.

Jacob, C. 1960. A Coefficient of Agreement for Nominal Scales. Educational and Psychological Measurement, 20, 37-46.

Langford, W.T, S.E. Gergel, T. G. Dietterich, and W. Cohen (2006) Map Misclassification Can Cause Large Errors in Landscape Pattern Indices: Examples from Habitat Fragmentation. Ecosystems 9: 474-488.

Hargis C. D., J.A. Bissonette, and D.L. Turner. 1999. The Influence of Forest Fragmentation and Landscape Pattern on American Martens. Journal of Applied Ecology 36: 157-172.

Huang C, Geiger E, and Kupfer JA (2006) Sensitivity of Landscape Metrics to Classification Scheme. International Journal of Remote Sensing 27: 2927-2948.

Helmi, M. (2007). Analisis Zonasi Ekosistem Alami Pulau Kecil dengan Pendekatan Ekologi Lanskap di Pulau Karimunjawa dan Kemajuan Taman Nasional Karimunjawa, Kabupaten Jepara, Jawa Tengah.

Helmi, M; A. Hartoko; H. Suko; Munasik dan Wouthuyzen, S. 2011. Analisis Respon Spektural dan Ekstraksi Nilai Spektral Terumbu Karang Pada Citra Digital MUltispektral Satelit ALOS-AVNIR di Perairan Gugus Pulau Pari, Kepulauan Seribu, Jakarta. Oseanografi Marina. Jurnal Nasional. Fakultas Perikanan dan Ilmu Kelautan, Universitas Diponegoro. Semarang, 1:120 - 136.

Kupfer, J. A. 2011. Theory in Landscape Ecology and Its Relevance to Biogeography. In: Millington A, Blumler M, and Schickhoff U (eds). Handbook of Biogeography. London: SAGE, 57-74.

Kupfer, J. A. (2012). Landscape Ecology and Biogeography: Rethinking Landscape Metrics in a PostFragstats Landscape. Progress in Physical Geography, 36(3), 400-420.

Li, H.B., and J.G. Wu. 2004. Use and Misuse of Landscape Indices. Landscape Ecology 19: 389-399.

Prasetya, J. D., and F. Purwanti, 2017. Mangrove Health Index as Part of Sustainable Management in Mangrove Ecosystem at Karimunjawa National Marine Park Indonesia. Advanced Science Letters, 23(4), 3277-3282.

Helmi, M., A. Satriadi, A. A. D. Suryoputro, J. Marwoto, H. Stiyono, and Hariyadi, 2018a, "Rehabilitation Priority Area Assessment on Death Coral using Cell Based Modeling Approach at Parang Islands, Karimunjawa National Park, Indonesia”, International Journal of Civil Engineering and Technology (IJCIET), IAEME Publication, Vol. 9, No. 11, pp. 2949-2961. 
Hidayati, N., T. R. Soeprobowati, and M. Helmi, 2018, "The Evaluation of Water Hyacinth (Eichhornia Crassiper) Control Program in Rawapening Lake, Central Java, Indonesia", ICSAE IOP Conf. Series: Earth and Environmental Science, 142 (2018) 012016 DOI :10.1088/17551315/142/1/012016

Suripin, D. Sugianto, and M. Helmi. 2017. Mangrove Restoration with Environment Friendly Permeable Breakwater. Asian Journal of Microbiology, Biotechnology \& Environmental Sciences Paper. Vol. 19, Issue 1, Page No. (102-107).

Helmi, M., Purwanto, W. Atmodjo and P. Subardjo, and A. Aysira, 2018b, "Benthic Diversity Mapping and Analysis Base on Remote Sensing and Seascape Ecology Approach at Parang Islands, Karimunjawa National Park, Indonesia", International Journal of Civil Engineering and Technology (IJCIET), Vol. 9, No. 11, pp. 227-235.

Kabiri, K., and, B. Pradhan, 2013. "A Novel Approach to Estimate Diffuse Attenuation Coefficients for QuickBird Satellite Images: A Case Study at Kish Island, the Persian Gulf", Indian Society of Remote Sensing, vol. 41, pp. 797-806, DOI: 10.1007/s12524-013-0293-0.

Danoedoro, P. 2012. Pengatar Penginderaan Jauh Digital. Penerbit Andi. DI Yogyakarta. Hlm 258-292.

Lillesand, T.M., Kiefer, R. W., and Chipman, J. 2008. Remote Sensing and Image Interpretation. 6th Edition. John Wiley and Sons. New York.

Wicaksono, P., and M. Hafiz, 2013, "Mapping Seagrass from Space: Addressing the Complexity of Seagrass LAI Mapping”, European Journal of Remote Sensing, no 1 vol. 46, pp. 18-39.

Sutanto. 2013. Metode Penelitian Penginderaan Jauh. Badan Penerbit Fakultas Geografi (BPFG), Universitas Gadjah Mada. Yogyakarta. hlm. 65-78.

McGarigal, K., S.A. Cushman, M.C. Neel, and E. Ene. 2002. Fragstats: Spatial Pattern Analysis Program for Categorical Maps. Computer Software Program Produced by the Authors at the University of Massachusetts, Amherst. Available at: www.umass.edu/landeco/ research/fragstats/fragstats.html.

Shao, G. and Wu, J. 2008. The Accuracy of Landscape Pattern Analysis Using Remote Sensing Data. Landscape Ecology 23: 505-511.

Satriadi, A., M. Helmi, and R. Redyansah, 2018, "Numerical Modeling of Tsunami in Jember Regency", Asian Jr. of Microbiol. Biotech. Env. Sc., Vol. 20, No. 3, pp. 87-91.

Setyawidati, N., A. H. Kaimuddin, I. P. Wati, M. Helmi, I. Widowati, and N. Rossi, 2017, "Percentage Cover, Biomass, Distribution, and Potential Habitat Mapping of Natural Macroalgae, based on High-resolution Satellite Data and in Situ Monitoring, at Libukang Island, Malasoro Bay, Indonesia", J. Appl. Phycol, Springer Science+Business Media B.V., DOI 10.1007/s10811-0171208-1.

Hartoko, A., M. Helmi, M. Sukarno, Hariyadi, 2016, "Spatial Tsunami Wave Modelling for The South Java Coastal Area, Indonesia”, International Journal of GEOMATE, Vol. 11, Issue 25, pp. 24552460 . 